\title{
PROFILE OF CARCINOMA LARYNX PATIENTS ATTENDING A TERTIARY CARE HOSPITAL IN WESTERN ODISHA
}

Satyajit Mishra, Sujata Panda

1. Assistant Professor, Department of ENT, V.S.S. Medical College, Burla, Odisha.

2. Senior Resident, Department of ENT, V.S.S. Medical College, Burla, Odisha.

\section{CORRESPONDING AUTHOR}

Dr. Satyajit Mishra, Assistant Professor, Dept. of ENT and Head and neck surgery, V.S. S. Medical College and hospital, Burla, Odisha. Pin - 768017

E-mail: dr.satyajitmishra@gmail.com, Ph: 00919437088951.

ABSTRACT: Carcinoma Larynx is a disease that affects people of western Odisha to a variable extent. This disease leads to high morbidity and mortality as well as a huge financial burden on the patients. We conducted a retrospective study on 82 no. of carcinoma larynx patients attending Department of E.N.T., V.S.S. Medical college hospital, Burla (Sambalpur) in western Odisha to have a knowledge data about its demographic pattern as well as clinicopathological aspects.

KEY WORDS: Carcinoma larynx, clinicopathological

INTRODUCTION: Carcinoma Larynx is a debilitating disease that leads to disruption in speech and respiration. The incidence of this disease is estimated to be 14 to $15 \%$ of all head and neck malignancies in various studies. $(1,2)$ In addition to the disease itself, their treatment modality too affects the quality of life of the patient. We conducted a study on the profiles of patients of carcinoma larynx attending V.S.S. Medical College, Burla- a premier tertiary care centre in Western Odisha- over a period of three years between 2006 and 2008 taking into consideration the different types of presentations, time of presentations etc. to have a broad data on this disease in this part of the country.

MATERIAL \& METHODS: A review of data of 82 no. of patients of Carcinoma Larynx between the periods 2006 to 2008 attending V.S.S. Medical College, Burla were reviewed. The data from Dep't. Of Radio Therapy were also taken into account. After a thorough history and physical examinations done, the patients were put for routine investigations and specialized investigations like Direct Laryngoscopy, Upper G.I. Endoscopy, CT Scan head and neck region and M.R.I ( if needed) along with pathological tests like F.N.AC, and Histopathological study.

RESULTS: Out of 33181 no. of patients coming to outpatient Dep't. Of V.S.S. Medical college Hospital, 744 were detected to have Head \& Neck Malignancy and 82 of them were Carcinoma Larynx patients as shown in Table 1 . The percentage of patients in relation to Head \& Neck Malignancy was $11.02 \%$. 
OCCUPATION: As shown in the table below, 43.9\% cases were agricultural workers followed by Industrial workers (19.5\%) and housewives. As Western Odisha has got a rich population of agricultural workers, it is but natural that maximum no. of patients belong to this category.

PREDISPOSING FACTORS: Smoking is extremely prevalent in the sufferers. Tobacco chewing and Alcoholism was noted in 58.53 and $21.95 \%$ of cases respectively. Tobacco chewing and alcohol consumption both were seen in $12(14.63 \%)$ of cases

SYMPTOMS AND SIGNS: Altered voice of an average duration of three months accounted for $97 \%$ of cases. Difficulty in deglutition and breathing accounted for $58 \%$ and $51 \%$ of cases respectively. Neck nodes were detected in $71 \%$ cases

SITES OF INVOLVE MENT AND HISTOPATHOLOGY: Regarding sub sites of larynx involved, by the time patients presented to our institute, more than one sub sites were affected-most commonly both Supra glottis and Sub-glottis were involved. Individually, Supra glottis was the predominant site to be involved.

All the cases were put for histopathological study and $98 \%$ of them came out to be Squamous cell carcinoma

DISCUSSION: Carcinoma of larynx with its varied presentation in a single set up is not unusual. Although the symptoms affect the day to day life as well as quality of life, still patients present at a variable time after onset of symptoms.

In our setup, the incidence was found to be more than $11 \%$ of Carcinoma of larynx in relation to all head and neck malignancies. Most of the cases presented in the sixth and seventh decade of life .Martin et al and Dutta Choudhary et al have reported similar pattern.,4 We found the average age of incidence for male to be 59 years, whereas for females it came to be 54 years. Males were affected quite highly (85\%) than females (14\%). Jose Guilherme vartanian et al (2005) had found a similar sex incidence ${ }^{5}$. Similar was the finding of Nasir Iqbal (2007) and Abhinandan Bhattacharjee et al (2006). ${ }^{1}$

Although people from lower socio economic status were more prone for incidence, there was no disparity in incidence between urban and rural population. Logically, most people from Western Odisha being dependent on agriculture, the incidence is quite high (49\%) in them. Most of the Indian studies ( J. Bakshi et al, Hemant Ahluwalia et al ) have also reported similar findings ${ }^{6,7}$. Smoking is a well recognised predisposing factor of Carcinoma larynx. We found more than three fourth of our sufferers were smokers.This finding is supported by the study of Jose Guilherme Vertanian et al. ${ }^{5}$

As the awareness regarding carcinoma larynx as well as health related issues being not an important issue with most of the people, maximum number of patients (75\%) were found to be node positive on presentation with more than $50 \%$ having $\mathrm{N} 1$ nodes and $9.75 \%$ being $\mathrm{N} 2 \mathrm{~b}$ nodes. Multiple sites of involvement (supraglottic and glottis) and stage 3 tumours were predominant in our study. The tumours were almost always Squamous cell carcinoma(>98\%) which is a common pattern in various studies by Kelly and Cross(1968),Myerson et al(1664),Nasir Iqbal (2007) and Kohtaroh Tanaka et al (2005).8,9,10

CONCLUSION: Ca larynx is a disease found more commonly in poor class people addicted to smoking and they being poorly health conscious present quite late in the hospital leading to 
poor treatment outcome in them. Therefore it is desirable to educate them about this disease so that early diagnosis and treatment can make a lot of difference in the morbidity and mortality.

\section{REFERENCE}

1. Abhinandan Bhattacharjee, A. Chakraborty, P.Purkaystha. Prevalence of Head and Neck cancer in the North East an Institutional Study. Ind. Jour. OF Otolaryngology and H\&N Surg. Vol. 58, No. 1,Jan-March. 2006.

2. Chandrasekhar,S.R.: Carcinoma of the pyriform fossa, Indian J. Otolaryng. 17:119,1965.

3. Martin,H.E.(1947):Quoted by Myerson(1964) (Ref. 68)

4. Dutta Choudhary, R. and Sen Gupta, B.K: A Clinicopathological study of cancer of the larynx and hypopharynx with special reference to aetiology. J. Indian M.A. $3219 ; 352,1959$.

5. Jose Guilherme vartanian, MD; Andro lopes carvalho,MD,PhD;Julia Toyota,R.N. et al: Socioeconomic effects of and risk factors for disability in longterm survivors of Head and Neck cancer. Arch.Otolaryngol Head Neck Surg. 2006;132:32-35.

6. Jaimanti Bakshi,Naresh K Panda,Suresh Sharma et al. Survival patterns in treated cases of Carcinoma Larynx in North India- A 10 year follow up study. Ind. Jour. of Otolaryng. and H\&N Surg. Vol.56,No.2,April-June(2004).

7. Hemant Ahluwalia,S.C Gupta, Mangal Singh et al. Spectrum of head and neck cancer at Allhabad. Ind.Jour. of Otolaryngol. And H\&N Surg.Vl.53, No.1, Jan-March,2001.

8. Kelly,W.D. and Cross,F.H.:Cancer of the Larynx.J.Laryng.82:537,1968.

9. Myerson,MC: The human larynx Charles C.Thomas, publishers springfiedIllinois

TABLE - I INCIDENCE OF MALIGNANCY LARYNX

\begin{tabular}{|l|l|l|l|l|l|}
\hline Year & $\begin{array}{l}\text { Total } \\
\text { Patients in } \\
\text { E.N.T. OPD }\end{array}$ & $\begin{array}{l}\text { Total cases of } \\
\text { Head and Neck } \\
\text { Malignancy }\end{array}$ & $\begin{array}{l}\text { Percentage of } \\
\text { Head \& Neck } \\
\text { Malignancy }\end{array}$ & $\begin{array}{l}\text { Total Cases of } \\
\text { Laryngeal } \\
\text { Carcinoma }\end{array}$ & $\begin{array}{l}\text { Percentage of } \\
\text { Ca larynx in } \\
\text { relation to } \\
\text { Head and Neck } \\
\text { Malignancy }\end{array}$ \\
\hline $\begin{array}{l}2006- \\
2008\end{array}$ & 33181 & 744 & $2.24 \%$ & 82 & $11.02 \%$ \\
\hline
\end{tabular}

Table 2 shows the the age \& sex distribution of patients. The most common age group to be affected was in the $5^{\text {th }}$ and $6^{\text {th }}$ decade at an incidence of $39 \%$, followed by $6^{\text {th }}$ and $7^{\text {th }}$ decade. The youngest case was of 35years and the oldest was of 85 years old.

Male patients far outnumbered female patients at a ratio of 6:1.

Table 2: AGE AND SEX INCIDENCE

\begin{tabular}{|l|l|l|l|l|}
\hline $\begin{array}{l}\text { Age group in } \\
\text { years }\end{array}$ & Male & Female & Total & Percentage \\
\hline $0-10$ & - & - & - & - \\
\hline $11-20$ & - & - & - & - \\
\hline $21-30$ & - & - & - & - \\
\hline
\end{tabular}




\section{ORIGINAL ARTICLE}

\begin{tabular}{|l|l|l|l|l|}
\hline $31-40$ & 2 & - & 2 & 2.44 \\
\hline $41-50$ & 11 & 5 & 16 & 19.51 \\
\hline $51-60$ & 28 & 4 & 32 & 39.02 \\
\hline $61-70$ & 22 & 2 & 24 & 29.27 \\
\hline $71-80$ & 5 & 1 & 6 & 7.31 \\
\hline Above 80 & 2 & - & 2 & 2.44 \\
\hline Total & $\mathbf{7 0}$ & $\mathbf{1 2}$ & $\mathbf{8 2}$ & $\mathbf{9 9 . 9 9}$ \\
\hline
\end{tabular}

TABLE - 3 SOCIO- ECONOMIC STATUS

\begin{tabular}{|l|l|l|}
\hline Socioeconomic Status & No. of cases & Percentage \\
\hline Upper Class & 6 & $7.32 \%$ \\
\hline Middle Class & 34 & $41.46 \%$ \\
\hline Lower Class & 42 & $51.22 \%$ \\
\hline Total & $\mathbf{8 2}$ & $\mathbf{1 0 0 . 0} \%$ \\
\hline
\end{tabular}

The above table shows that more than 50\% (51.22) came from poor class and only7.3\% were rich.

HABITAT: Patients of both rural and urban were almost equally affected

TABLE-4 HABITAT

\begin{tabular}{|l|l|l|}
\hline Habitat & No. of cases & Percentage \\
\hline Rural & 43 & $52.4 \%$ \\
\hline Urban & 39 & $47.6 \%$ \\
\hline Total & 82 & $100 \%$ \\
\hline
\end{tabular}

TABLE-5 OCCUPATION

\begin{tabular}{|l|l|l|}
\hline Occupation & No. of Cases & Percentage \\
\hline Agricultural Worker & 36 & $43.9 \%$ \\
\hline Labourer & 4 & $4.88 \%$ \\
\hline Office Worker & 15 & $18.3 \%$ \\
\hline Factory Worker & 16 & $19.5 \%$ \\
\hline House Wives & 11 & $13.42 \%$ \\
\hline Total Cases & $\mathbf{8 2}$ & $\mathbf{1 0 0 . 0}$ \\
\hline
\end{tabular}

TABLE - 6 PERSONAL HABITS

\begin{tabular}{|l|l|l|}
\hline Personal Habits & No: of cases & Percentage \\
\hline Non-vegetarian & 53 & $64.6 \%$ \\
\hline Vegetarian & 29 & $35.4 \%$ \\
\hline Alcoholic & 18 & $21.95 \%$ \\
\hline Non-alcoholic & 64 & $78.05 \%$ \\
\hline Smoker & 62 & $75.61 \%$ \\
\hline
\end{tabular}


ORIGINAL ARTICLE

\begin{tabular}{|l|l|l|}
\hline Non-smoker & 20 & $24.39 \%$ \\
\hline Tobacco Chewing & 48 & $58.53 \%$ \\
\hline $\begin{array}{l}\text { Tobacco chewing } \\
\text { and Alcoholism }\end{array}$ & 12 & $14.63 \%$ \\
\hline Betel Chewing & 32 & $39.02 \%$ \\
\hline
\end{tabular}

TABLE - 7 SYMPTOMATOLOGY

\begin{tabular}{|l|l|l|l|l|l|l|}
\hline \multirow{2}{*}{ Symptoms } & \multicolumn{4}{|l|}{ Duration in Months } & $\begin{array}{l}\text { Total no } \\
\text { of cases }\end{array}$ & Percentage \\
\cline { 2 - 6 } & $\mathbf{0 - 3}$ & $\mathbf{4 - 6}$ & $\mathbf{7 - 1 2}$ & $\mathbf{> 1 2}$ & \\
\hline Hoarseness of Voice & 52 & 23 & 4 & 1 & 80 & $97.56 \%$ \\
\hline $\begin{array}{l}\text { Difficulty in } \\
\text { Swallowing }\end{array}$ & 36 & 9 & 3 & 0 & 48 & $58.54 \%$ \\
\hline Difficulty in breathing & 37 & 5 & 0 & 0 & 42 & $51.22 \%$ \\
\hline $\begin{array}{l}\text { Throat irritation (F.B } \\
\text { Sensation) }\end{array}$ & 45 & 6 & 5 & 0 & 56 & $68.29 \%$ \\
\hline Pain in throat & 19 & 3 & 0 & 0 & 22 & $26.83 \%$ \\
\hline Lump in neck & 24 & 8 & 5 & 2 & 59 & $71.95 \%$ \\
\hline Ear ache & 11 & 6 & 1 & 0 & 19 & $23.17 \%$ \\
\hline Cough & 42 & 17 & 2 & 1 & 62 & $75.61 \%$ \\
\hline Weight Loss & 39 & 12 & 3 & 4 & 58 & $70.73 \%$ \\
\hline Fetor & 29 & - & - & - & 29 & $35.36 \%$ \\
\hline Cachexia & 5 & 3 & - & - & 8 & 9.75 \\
\hline Stridor & 23 & - & - & - & 23 & $28.04 \%$ \\
\hline
\end{tabular}

TABLE - 8 LYMPH NODE METASTASIS

\begin{tabular}{|l|l|l|}
\hline Lymph node & No. of cases & Percentage \\
\hline Neck nodes (Total No. of cases) & 59 & $74.95 \%$ \\
\hline Ipsilateral single node $\left(\leq 3 \mathrm{~cm}\left(\mathrm{~N}_{1}\right)\right)$ & 43 & $52.44 \%$ \\
\hline Ipsilateral single node $\left(>3\right.$ and $\left.\leq 6 \mathrm{cms}\left(\mathrm{N}_{2 \mathrm{a}}\right)\right)$ & 2 & $2.44 \%$ \\
\hline Ipsilateral multiple nodes $\left(\leq 6 \mathrm{cms}\left(\mathrm{N}_{2 \mathrm{~b}}\right)\right)$ & 8 & $9.75 \%$ \\
\hline Bilateral $\leq 6 \mathrm{~cm}\left(\mathrm{~N}_{2 \mathrm{c}}\right)$ & 5 & $6 \%$ \\
\hline Lymph node $>6 \mathrm{cms}\left(\mathrm{N}_{3}\right)$ & 1 & $1.22 \%$ \\
\hline
\end{tabular}

TABLE -9 HISTOPATHOLOGICAL EXAMINATION

\begin{tabular}{|l|l|l|}
\hline Cytology & No. of cases & Percentage \\
\hline Squamous cell carcinoma & 81 & $98.78 \%$ \\
\hline Adenocarcinoma & 1 & $1.22 \%$ \\
\hline Total & 82 & $100 \%$ \\
\hline
\end{tabular}




\section{ORIGINAL ARTICLE}

TABLE NO -10 T-STAGING

\begin{tabular}{|l|l|l|}
\hline staging & No of cases & Percentage \\
\hline $\mathrm{T}_{1}$ & 12 & $14.63 \%$ \\
\hline $\mathrm{T}_{2}$ & 16 & $19.51 \%$ \\
\hline $\mathrm{T}_{3}$ & 45 & $54.88 \%$ \\
\hline $\mathrm{T}_{4}$ & 9 & $10.98 \%$ \\
\hline TOTAL & $\mathbf{8 2}$ & $\mathbf{1 0 0} \%$ \\
\hline
\end{tabular}

Maximum no. of cases in our series were in $\mathrm{T} 3$ stage when they came to the hospital. 